working of the land. It differed, however, from the Scottish example in that some sixty years ago social stratification was more pronounced than it is to-day. At this time the local gentry were definitely the leaders. It was they who set the standards for emulation and were the innovators of changes in agriculture. This would appear to confirm what Mr. Moisley had said about Hebridean society, namely, that diversification in social structure and in size of land-holding facilitates natural leadership. The contrast between the Anglicized, churcb-going squires and the Welsh-speaking, Nonconformist peasantry in Wales at the turn of this century was great indeed, and leadership in many matters fell to the squires. Two World Wars and the coming of the Welfare State eclipsed the squires, and Mr. Jenkins showed that those who took their place in South Cardiganshire were not necessarily the agricultural advisers but individuals who for some reason or other did not conform to the conventions of the existing society. For example, a man who was not a member of any chapel and went to the South of France for his holidays might be the first farmer to introduce a tractor or a combined harvester on his farm. Similarly, a farmer who was known to be in debt and had quarrelled with his minister and never appeared in chapel or frequented the local public house was likely to be the first to introduce electrical fencing on his farm. Other farmers later would follow suit. It was clear that in this society there was a sharp distinction between 'bobl y capel' (the chapel people) and 'bobl y byd' (the people of the world). Leadership and innovation after the eclipse of the squires came, as it were, from 'the odd man out' in the local social set-up, and he would inevitably belong to 'the people of this world' rather than to 'bobl $y$ capel'.

The importance of the religious factor in social leadership was stressed also by Miss R. L. Harris, whose contribution to the discussion dealt with leadership in a border community in Northern Ireland. She emphasized the distinction between formal and informal leadership and stressed that the local clergyman was unquestionably the most important formal leader in this society. Members of the community were very reluctant to assume the role of overt leader. Miss Harris paid special attention to the relationships between the local people and such leaders. The local people tended to judge the overt leader on his or her ability to meet outsiders on equal terms, and it was only natural that Irish people would keep a very close watch on overt leaders from outside the community.

The fourth speaker, Mr. M. Kirk, whose study concerned villages in Yorkshire and Devonshire. made the audience feel the force of the impact of urban civilization on rural life in modern times to a much greater extent than any of the other speakers were able to do. One felt that Mr. Kirk's studies of these English rural communities had the advantage of emphasizing how important are the urbanizing and centralizing forces in modern English life. His title told the whole story-"The Suburban Community in the Countryside". He showed how a large number of English villages were no longer traditionally rural, because so many of their inhabitants included those who had chosen to live in the country, but derived their economic and social status from an urban setting. Village life, in consequence, has decayed. Very often the nominal leader (for example, the elected representative of the community on the rural district council) would be a retired city businessman who had come to live in the village. On the other hand, the native villagers complain that there are not enough men to form a football team, or enough women to run a successful dance. The village is clearly not what it was-in fact, according to Mr. Kirk it has ceased to exist, although its population is actually increasing. Under these conditions local leadership is at a low ebb, while initiative and innovation tend to pass to the central administration functioning through the national ministries.

The general discussion that followed the opening papers may be said to have been disappointing. There are several reasons for this. In the first place, the opening papers were specialized and presented by experts who had the advantage of considerable experience in the field. It is difficult to discuss factual data presented in this way. Furthermore, the four papers were so diverse in character that they did not lend themselves to the formulation of general conclusions, while, in addition, there was the point concerning the geographers already mentioned. One of the speakers in the open forum stressed the importance of university extension classes in rural areas in the training of leaders, while another underlined the fact, already apparent, that as centralized controls increase, local leaders decrease.

E. G. Bowen

\title{
PESTS OF STANDING CROPS
}

CECTION D (Zoology) of the British Association, $\$$ during the recent meeting at Cardiff, arranged a morning session under this title since the problems raised in the attempts to understand animal population dynamics are not only interesting in themselves, but also have important applications to studies of crop pests, and some of the basic ideas are relevant to human population studies. At the plenary session of the Association on "World Food and Population", Sir Charles Darwin expressed a point of view close to that of many zoologists, but he spoke for less than five minutes. So it was fortunate that Section D had the opportunity for its own discussion, during the following morning, under the chairmanship of Mr. H. R. Hewer.
Prof. G. C. Varley, of Oxford, sought to relate the contribution of zoologists to problems of human food supply and human population. The symposium of the previous day showed the extent to which men of science are still working as if in watertight compartments. Their work is unco-ordinated, and in human affairs its impact is in opposing directions. Advances in medicine have enormously reduced human suffering and (to our satisfaction as individuals) increased our expectation of life. The reduction of mortality from disease and the increased fertility which accompanies good health have, however, increased the rate of population growth in many parts of the world.

Agricultural experts tend to accopt as inevitable 
a great rise in human population, and rightly claim that if given the means they can provide the extra food required-for the next forty years at least. Is it not time now to take a long view and to consider how the world population is to be stabilized ? Present work is tending to make the eventual solution more difficult. If gerontologists find an easy way to prolong human life far beyond the normal span. the resultant change in the age structure of the population and its rapid increase in size might in fact precipitate a great disaster for the human race.

Many zoologists find ideas like those of Malthus still helpful in studies of animal populations. His prediction late in the eighteenth century that "misery and vice" would result if the population of the British Isles rose much further seemed so convincing that plans for a regular census of the population were made. Now, when the population has risen more than fourfold and the standard of living has also improved, how wrong poor Malthus appears! But was not his error simply his failure to foresee the industrial revolution, with its railways, road transport and steamships to bring food to these islands ?

Forty years ago, Pearl fitted sigmoid logistic curves to human populations and extrapolated these to find steady limiting values. We shall not know for another century how right he was, but similar logistic curves describe very well the growth of populations of some insects, such as flour beetles, given a regular energy supply in the form of food. The population limit is reached when the birth-rate equals the death. rate; as crowding increases, the death-rate rises and the birth-rate falls. Whether the differences in human birth-rate between urban and country districts are a similar phenomenon is debatable.

The more complex problems of animal populations of two or more species living together are by no means fully understood. Consideration of the energy-flow in such systems helps in understanding them. Solar energy (about 0.1 per cent of it) is made available as human food by crop plants. Insect pests compete for this energy, and themselves serve as an energy source to their predators and parasites, which may be eaten by other animals. The fraction of available energy lost at each stage of conversion is very high. To support the greatest human population, pests must be kept down in numbers. Sir Alexander Fleck suggested that ehemists have provided the method to do this and indeed they can give great help ; but it must be emphasized that the problems raised are biological problems of some complexity. Animal populations in the wild and laboratory populations under constant conditions both can show violent fluctuations in numbers, the interpretation of which is still a subject for controversy. Although as yet insufficiently tested, mathematical models are available which can explain populationcycles, and some models can explain in principle why insecticides reduce the average population-levels of some pests but increase the population-levels of certain others.

Mr. D. W. Wright, of the National Vegetable Research Station, Wellesbourne, described his work on the cabbage root fly, the maggots of which feed on the plant's root system. The cabbage then suffers from water- and mineral-deficiency and is stunted or killed. Commonly about a third of the yield is lost, but this can be prevented by the careful application of suitable insecticides to the roots. However, where insecticides like DDT are used broadcast, or applied with plant fertilizers, very severe post damage may result. This is because a high proportion of root fly eggs, clustered around the cabbage stem, are normally eaten by predatory ground beetles of the genus Bembidion, and low concentrations of insecticide affect these wandering predators far more than the relatively immobile meggots. Field experiments designed either to eliminate the beetles, or to concen. trate them within certain areas, have shown conclusively the important role these beetles normally take in limiting the severity of damage by the cabbage root fly.

Dr. G. H. L. Dicker and Mr. R. C. Muir, of East Malling Research Station, considered some fruit pest problems. Toxic chemicals are widely used in com. mercial orchards and the obstacle to success is usually lack of knowledge of the biology of the pests and their natural enemies, and of the behaviour of the chemicals in the field, rather than a shortage of suitable chemicals. Regular applications of insecticides in early. spring have virtually eliminated some pests like the once troublesome apple blossom weevil. Codling moth presents much greater problems. This moth lays its eggs on the young fruits of apple over a period of eight weeks or more. Very soon after hatching, the young caterpillars enter the fruits, where they can no longer be reached by insecticides. Whereas DDT suitably applied can remain sufficiently toxic over the long period of caterpillar hatching and will kill most of the larvæ before they enter a fruit, trces so treated commonly suffer severe damage from red spider mite, the predators of which are killed by DD'T. The use of a further chemical spray to kill the mites was formerly effective, but the mite has now evolved resistance to a wide variety of chemicals. Special spray schedules designed to interfere as little as possible with predators of the mites are at present under investigation both in Kent and in Nova Scotia, and the results are promising.

The basis of plant resistance to insect attack remains poorly understood, but an apple rootstock resistant to woolly aphis is now available; this project took thirty years from its inception to eventual release on a commercial scale. Even so, success may only be temporary : a raspberry variety supposedly resistant to raspberry aphid was found susceptible to attack by a previously untested strain of the aphid.

A paper by Dr. R. F. Morris and Dr. C. A. Miller, of the Forest Biology Laboratory, Fredericton. N.B., Canada, on the population dynamies of some native and introduced forest insects in the Atlantic Provinces of Canada summarized long-term population changes and went a considerable way to suggest causes for them. Many of the native pests of the extensive spruce and balsam fir forests seem to have small population peaks every five to eight years, but never become common enough to cause visible damage to the trees. In contrast, the black-headed budworm has maxima on the average every seven years, and in the late 'twenties and again in the late 'forties trees were defoliated; but the population-level diminished again without the trees being killed. A study of the changes in the numbers of the hymenopterous parasites of the budworm suggests that this is an example of Nicholsonian host-parasite population oscillations. The cycles in widely separated populations in eastern Canada seem to be in phase, which suggests that sorne common extrinsic factor such as weather has an 
effect on the periodicity. Cycles of abundance of the fall webworm can be traced from historical records so far back as 1770 . The interval between outbreaks is between nine and thirteen years. In Nova Scotia the population peaks are high enough to defoliate trees whereas in New Brunswick the maxima are never so high ; this curious difference in status could provide a lead to new methods of control and it is being investigated.

The spruce budworm is the major native pest of the spruce and balsam fir forests. At intervals of some forty years it has killed the trees over hundreds of square miles. The numerous species of parasites and predators which attack the spruce budworm when its numbers are low seem unable to increase quickly when the budworm outbreaks begin, and indeed seem to shun defoliated areas of the forest. The most recent outbreak began in the middle 'forties and, at its height, to save the trees more than 200 aircraft were used to spray insecticide over some 5 million acres of forest.
The introduced European spruce sawfly caused serious damage to the trees in the 'twenties. Various parasites were then imported and liberated, and some became established. For the past twenty years, these and a virus disease which was apparently introduced accidentally have kept the species below a level at which damage is significant. Time will show whether. current projects for the biological control of the introduced winter moth, larch case bearer and balsam woolly aphid will eventually be successful. Only a very few years ago, biological control was regarded as possible only on oceanic islands or perhaps as an exception in California !

These papers are representative of the sort of long. term work which is now being undertaken in agricultural and forest entomology. There is clearly a great need for more applied research, but this will be easier to plan when there is more basic knowledge of the behaviour of pests and their predators and parasites, especially in relation to changes in their food supplies and population densities. G. C. VARLEY

\section{GULIELMA LISTER CENTENARY}

$\mathrm{M}$ ISS GULIELMA LISTER, born on October 28, 1860, at 871 High Road, Leytonstone, Essex, where she died on May 18, 1949 (ref. 1), was one of those distinguished amateur naturalists of professional competence who have done so much to advance and deepen biological knowledge. She came of an intellectual Quaker stock-her father, Arthur Lister, F.R.S. (1830-1908), was a son of J. J. Lister, F.R.S. (1786-1869), and a brother of Lord Lister (18271912), the surgeon-and apart from a year at Bedford College she was educated at home. The course of her long life showed her to be able and industrious, economical and generous, a painstaking and accurate observer, and artistic, while her attractive personality gained her many friends. Her interests in natural history were exceptionally wide, and her detailed field knowledge of both the fauna and the flora must frequently have embarrassed specialists. Miss Lister was for many years an active member of the Essex Field Club, towards which she maintained a special affection, the Nature Study Union, and the Linnean Society, and she was twice president of the British Mycological Society. She had many calls on her artistic ability, and made notable minor contributions to botanical art in such works as her cousin F. J. Hanbury's "Illustrated Monograph of the British Hieracia" (1889-98), with its beautiful hand-coloured plates, and in addition did more utilitarian illustrations for Dallimore and Jackson's "Handbook of the Coniferae" (1923), and other publications.

Miss Lister and her father will for long be best remembered as world authorities on the Myxomycetes or Mycetozoa, an interesting, distinctive, and compact group of organisms which, as its names imply, has been approached by botanists and zoologists with a certain ambivalence. The slime moulds, now generally accepted as a fungal group, are æsthetically attractive and are of world-wide distribution. Their classification is based mainly on their macroscopic and gross microscopic characters, and as they make excellent herbarium specimens they have been widely collected and preserved so that ample material is available for their study. It is to the Listers that much credit must be given for the reasonable chance of success that now attends the attempted identification of a myxomycete from any part of the world.

Arthur Lister, like his father, a wine merchant, had life-long interests in natural history and first turned his attention to Myxomycetes in 1887, his fiftyseventh year. After a hesitant start, he applied himself to the group with vigour, and accompanied by his daughter (as amanuensis and artist, though no mean draughtsman himself) he worked over the collections of Myxomycetes at the British Museum, the Royal Botanic Gardens, Kew, and the Paris Natural History Museum, as well as de Bary's collec. tions at the University of Strasbourg, and as a result the first edition of his "Monograph of the Mycetozoa" appeared in 1894 under the imprint of the British Museum (Natural History). After the death of her father, Miss Lister continued to study Myxomycetes for another forty years. She was responsible for the second edition of the "Monograph" (1911) and for the enlarged third edition (1925) (now unfortunately out of print and much sought after), which were lavishly illustrated in colour due to Miss Lister's generosity.

The "Monograph" is firmly based on specimens, many of which are in the British Museum (Natural History), and its background is well documented not only by the published papers of the Listers themselves and their correspondents but also in a series of seventy-four manuscript note-books (now in the possession of the British Mycological Society ${ }^{2}$ ) extending over a continuous period of sixty years, which give a fascinating picture of the day-to-day progress of the investigation, the routine of which went on uninterrupted whether at home in Leytonstone or at the Lister's' seaside house at Lyme Regis. The method of notekeeping was simple. Strongly bound, thick, school exercise books of lined paper were used, and notes were entered chronologically. Entries were made giving details of collections examined, the gist of letters received and of the replies. the notes frequently being accompanied by elaborate and often highly artistic water-colour drawings-- 